\title{
Effect of Electric Voltage on the Photocatalytic Oxidation Disinfection of Water Used in Real Estate
}

\author{
C. W. Kan, Y. N. Pan, and H. Chua
}

\begin{abstract}
In this study, a photocatalytic oxidation system was used for the disinfection of water used in a real estate in Hong Kong, two types of domestic water namely fountain water and flushing water were used in study to test the disinfection effectiveness done by photocatalytic oxidation system. Chlorine was used in the photocatalytic oxidation system for disinfection which is using $\mathrm{RuO}_{2}$ electrolytic and $\mathrm{TiO}_{2}$ photocatalytic system. This study was used to evaluate the formation and the disinfection efficiency of the free chlorine generated by the photocatalytic oxidation system under different electric voltages of 10, 20 and $30 \mathrm{~V}$. Experimental results revealed that under electric voltage of 25 to $30 \mathrm{~V}$, the best disinfection effect could be achieved.
\end{abstract}

Index Terms-Photocatalytic oxidation, disinfection, fountain water, flushing water.

\section{INTRODUCTION}

Photocatalytic oxidation (PCO) disinfection is an electro-activation technology capitalizes on a special coating technique of a specifically designed formula of ornamented titanium dioxide on D.C. electrodes [1]-[3]. The electrically activated coated surfaces transform naturally occurring chloride ions in water into activated chlorine with effective disinfecting power. This technology has been modified into a compact system that has small footprint, low power consumption, no chemical addition requirement, fully automatic operation, stable and reliable water disinfection system.

Secondly, PCO component in the system utilizes $\mathrm{TiO}_{2}$ as a photocatalyst to generate oxidation/reduction reactions. When a photo catalyst medium is exposed to radiation of ultraviolet rays, energized electrons will break free from the $\mathrm{TiO}_{2}$ coating [1], [2]. These electrons leave behind positively charged pockets called "positive holes". The positive holes vigorously attract hydroxide ions $\left(\mathrm{OH}^{-}\right)$from ambient water. The positive holes then take an electron from an $\mathrm{OH}^{-}$turning it into an extremely unstable $\mathrm{OH}$ hydroxyl radicals [4]. To stabilize themselves, the $\mathrm{OH}$ hydroxyl radicals take electrons from nearby organic compounds and pollutants. This breaks up the water-borne organic compounds, including bacteria and viruses, thus decomposing them into harmless carbon

Manuscript received April 22, 2014; revised June 23, 2014. This work was supported by the Teaching Company Scheme under The Hong Kong Polytechnic University.

C. W. Kan and Y. N. Pan are with the Institute of Textiles and Clothing, The Hong Kong Polytechnic University, Hung Hom, Kowloon, Hong Kong (e-mail: tccwk@polyu.edu.hk,pyl860305@gmail.com).

H. Chua is with Faculty of Science and Technology, Technological and Higher Education Institute of Hong Kong, 20A, Tsing Yi Road Tsing Yi Island New Territories (e-mail: hchua@vtc.edu.hk). and water that are released into the air [5], [6].

Thus, in this study, PCO developed with $\mathrm{RuO}_{2}$ electrolytic and $\mathrm{TiO}_{2}$ photocatalytic system will be used for real estate water disinfection system. Two types of domestic water namely fountain water and flushing water will be studied. Chlorine will be used in this disinfection system. The formation and the disinfection efficiency of the free chlorine generated by the photocatalytic oxidation system under different electric voltages will be studied.

\section{EXPERIMETAL}

\section{A. Domestic Water in Real Estate}

This study was conducted in a private real estate in Hong Kong and two types of domestic water namely fountain water and flushing water. Fig. 1 and Fig. 2 show the view of the location of fountain water and flushing water respectively.

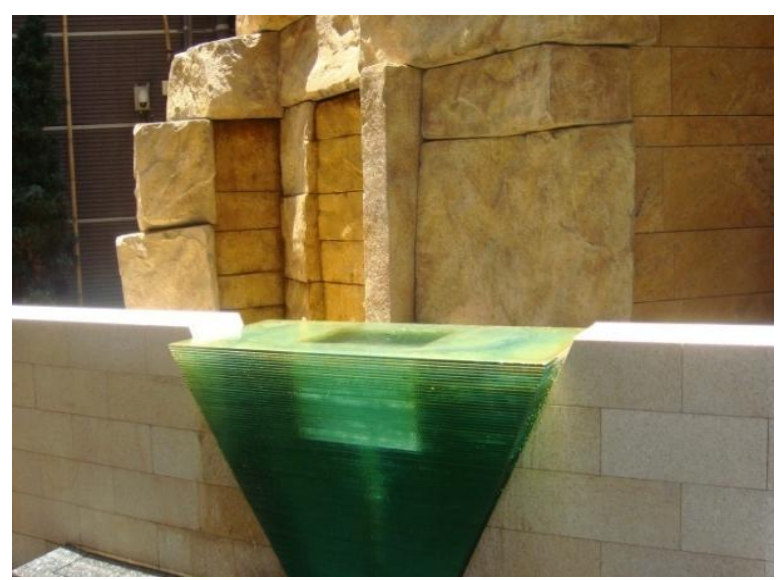

Fig. 1. View of location of fountain water

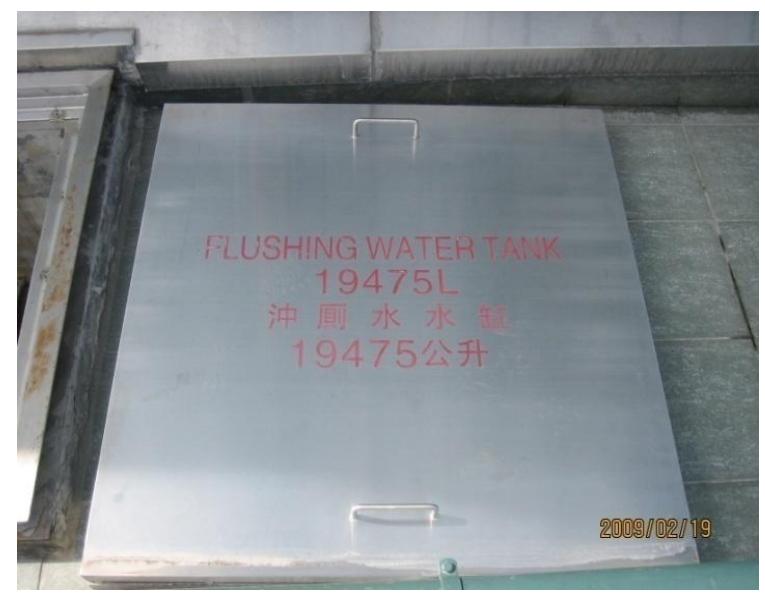

Fig. 2. View of location of flushing water.

B. Photocatalytic Oxidation (PCO) Disinfection System

A bench-scale PCO disinfection system using $\mathrm{RuO}_{2}$ 
electrolytic and $\mathrm{TiO}_{2}$ photocatalytic system was used and Fig. 3 shows the schematic diagram of the system. A water tank of $70 \mathrm{~L}$ was connected to the system.

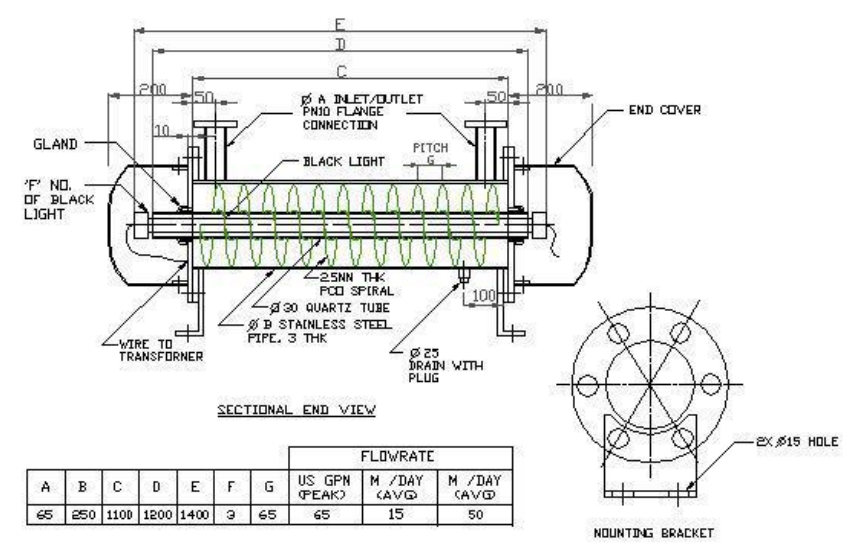

Fig. 3. Schematic diagram of a bench-scale PCO disinfection system.

\section{Operation Parameters}

A total volume of $70 \mathrm{~L}$ domestic water was filled in the tank for testing. The amount of $100 \mathrm{mg} / \mathrm{l}$ chloride ion in the domestic water was adjusted by adding sodium chloride $(\mathrm{NaCl})$. In this study, the electric voltage applied in water electrolysis processes was varied with 10, 20 and $30 \mathrm{~V}$.

The water samples in the tank were pumped to pass the electrolytic-photocatalytic device and then returned to the tank and recycled at the flow rate of $2 \mathrm{~m}^{3} / \mathrm{h}$. The flow rate was controlled by a series of control valves and internal recirculation circuits. Flow rate, $\mathrm{pH}$ and temperature were fixed during the test. The concentration of free chlorine was monitored during the process of electrolysis at each 5 minutes interval. The free chlorine concentration shown in the Results and Discussion section was regarded as the free chlorine in the water tank.

The effectiveness of this process was quantified by evaluating the total bacteria that were removed in the process. The method for bacterial enumeration was as follows: The microbial culture media, glassware, deionised water were sterilized in an autoclave at $121^{\circ} \mathrm{C}$ for $15 \mathrm{~min}$. Dilutions of microbial samples were carried out using sterilized deionised water. An appropriate sample volume was filtered through a sterile membrane filter. The filter papers were then placed on the surface of a plate containing agar medium for determining total bacteria content, and were incubated at $38^{\circ} \mathrm{C}$ for 48 hours. The colonies were counted in a standard microbial counter after the complete cycle of incubation.

\section{RESUlTS AND DISCUSSION}

\section{A. Fountain Water}

\section{1) Effect of electric voltage on bacterial content}

The method for bacterial enumeration was as follows: The microbial culture media, plastics ware, deionised water were sterilized in an autoclave at $121^{\circ} \mathrm{C}$ for $15 \mathrm{~min}$. Dilutions of microbial samples were carried out using sterilized deionised water. An appropriate sample volume was filtered through a sterile membrane filter. The filter papers were then placed on the surface of a plate containing agar medium for determining total bacteria content, and were incubated at $32^{\circ} \mathrm{C}$ for 48 hours. The colonies were counted in a standard microbial counter after the complete cycle of incubation. The results are shown in Table I and Fig. 4.

The effect of electric voltage on the generation of free chlorine by the electro-photo-disinfection system was determined by varying the voltage from 10 to $30 \mathrm{~V}$ at different contact time. The results of free bacterial disinfection at different voltage were illustrated in Fig. 4.

Under lower voltage $(10 \mathrm{~V})$, the current was small in the system, therefore, the rate of bacterial disinfection was also very slow. When the voltage was increased to $20 \mathrm{~V}$, the rate of bacterial disinfection was significantly increased. There were $3 \sim 5$ clones on a plate after 60 minute operation. As the electric voltage was further increased to $30 \mathrm{~V}$, the formation of free chlorine was substantially increased due to the higher current applied. The reaction time required to kill the bacterial to 3 5 clones was shortened to 30 mins. The amount of bacterial under various electrode voltages was presented in Table I.

TABLE I: BACTERIA VARIATION WITH TIME AND VOLTAGE FOR FOUNTAIN WATER

\begin{tabular}{cccc}
\hline \multirow{2}{*}{ Time (min) } & \multicolumn{3}{c}{ Bacteria (/plate) } \\
\cline { 2 - 4 } & $10 \mathrm{~V}$ & $20 \mathrm{~V}$ & $30 \mathrm{~V}$ \\
\hline 0 & $34 \sim 35$ & $32 \sim 33$ & $30 \sim 33$ \\
15 & $33 \sim 34$ & $30 \sim 31$ & $23 \sim 25$ \\
30 & $27 \sim 29$ & $17 \sim 19$ & $2 \sim 4$ \\
45 & $18 \sim 20$ & $10 \sim 11$ & 0 \\
60 & $11 \sim 13$ & $3 \sim 5$ & 0 \\
\hline
\end{tabular}

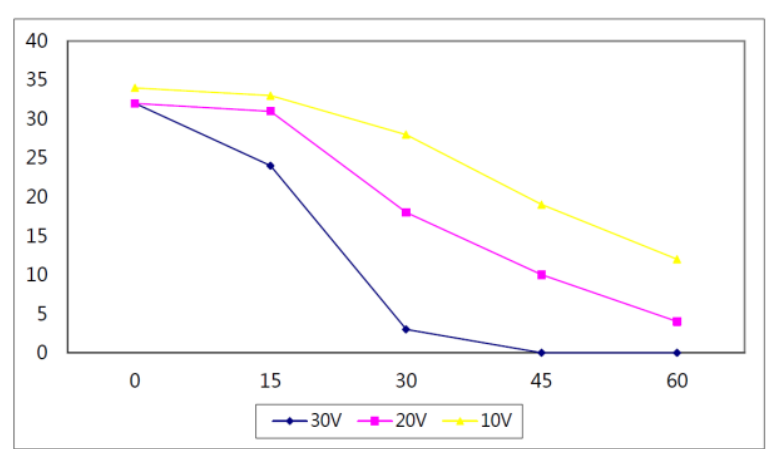

Fig. 4. Bacteria variation with time and voltage for fountain water (x-axis indicates the treatment time while the $y$-axis indicates the amount of bacteria).

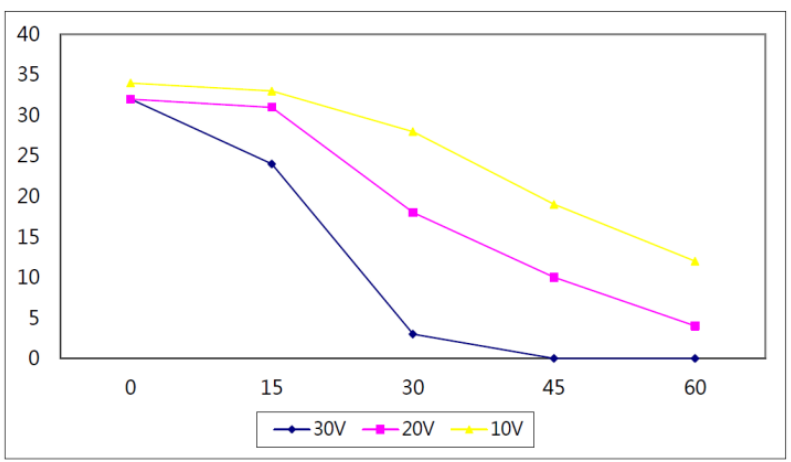

Fig. 5. Chlorine concentration variation with time and voltage for fountain water.

From the results, it is revealed that the amount of bacteria decreased by increase electric voltage. The voltage of $25 \mathrm{~V}$ or 
$30 \mathrm{~V}$ is the best voltage.

\section{2) The effect of electric voltage on free chlorine content}

The effect of electric voltage on the generation of free chlorine by the electro-photo-disinfection system was determined by varying the voltage from 10 to $30 \mathrm{~V}$ at different contact time. The results of free chlorine generation at different voltages and different contact time are illustrated in Fig. 5.

Under lower voltage $(10 \mathrm{~V})$, the current was small in the system, therefore, the rate of free chlorine formation was also very slow. When the voltage was increased to $20 \mathrm{~V}$, the rate of chlorine generation was significantly increased. The concentration of free chlorine in the water reached about 1.9 $\mathrm{mg} / \mathrm{l}$ after 60 -minute operation.

As the electric voltage was further increased to $30 \mathrm{~V}$, the formation of free chlorine was substantially increased due to the higher current applied. The reaction time required to generate $1.9 \mathrm{mg} / \mathrm{l}$ free chlorine was shortened to $15 \mathrm{mins}$ for $30 \mathrm{~V}$. As the electrolysis went on, the concentration of free chlorine accumulated. This indicated that the system is capable of generating a free chlorine production rate that reaches a dynamic equilibrium with the rate of chlorine consumption in the fountain water disinfection process.

The concentrations of free chlorine formed under various electrode voltages are presented in Table II. When chloride concentration was controlled above a certain value, the formation of free chlorine was positive and was proportional to the electric voltage applied across the electrodes. The higher the voltage applied in electrode, the higher rate of free chlorine formation in the water. The electric voltage should be applied to the system for effective disinfection is shown in Table II, in order to acquire sufficient free chlorine (1 to 3 $\mathrm{mg} / \mathrm{l})$ in the fountain water for effective disinfection. The optimum operational condition of this system is $30 \mathrm{~V}$.

TABLE II: CHLORINE CONCENTRATION VARIATION WITH TIME AND ELECTRIC VOLTAGE FOR FOUNTAIN WATER

\begin{tabular}{cccc}
\multicolumn{3}{c}{ ELECTRIC VOLTAGE FOR FOUNTAIN W ATER } \\
\hline \multirow{2}{*}{$\begin{array}{c}\text { Time intervals } \\
\text { (mins) }\end{array}$} & \multicolumn{3}{c}{ Chlorine concentration $(\mathrm{ppm})$} \\
\cline { 2 - 4 } $10 \mathrm{~V}$ & 1.53 & $20 \mathrm{~V}$ & $30 \mathrm{~V}$ \\
\hline 0 & 1.51 & 1.55 & 1.51 \\
30 & 1.53 & 1.57 & 1.92 \\
45 & 1.54 & 1.77 & 2.17 \\
60 & 1.55 & 1.86 & 2.15 \\
\end{tabular}

From the results, it is noted that the free chlorine concentration is increasing by increasing the electric voltage. The voltage of $25 \mathrm{~V}$ or $30 \mathrm{~V}$ is the best electric voltage.

Based on the results, it can conclude that with the increasing of electric voltage, the free chlorine content would be increased. As a result, the disinfection efficiency increases accordingly for the fountain water.

\section{B. Flushing Water}

\section{1) The effect of electric voltage on bacterial content}

The effect of electric voltage on the generation of free chlorine by the electro-photo-disinfection system was determined by varying the voltage from 10 to $30 \mathrm{~V}$ at different contact time. The results of free bacterial disinfection at different voltage were illustrated in Fig. 6.

Under lower voltage $(10 \mathrm{~V})$, the current was small in the system, therefore, the rate of bacterial disinfection was also very slow. When the voltage was increased to $20 \mathrm{~V}$, the rate of bacterial disinfection was significantly increased. There were 5 clones on a plate after 60 minute operation.

As the electric voltage was further increased to $30 \mathrm{~V}$, the formation of free chlorine was substantially increased due to the higher current applied. The reaction time required to kill the bacterial to 5 clones was shortened to 30 mins. The amount of bacterial under various electrode voltages was presented in Table III.

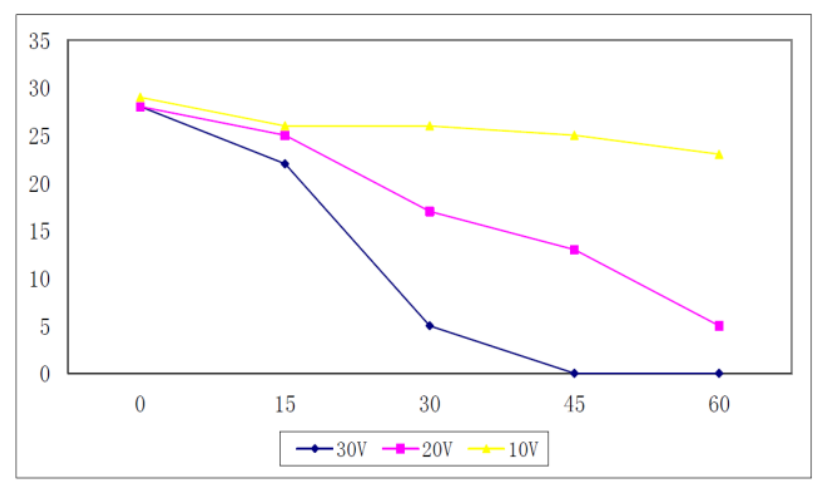

Fig. 6. Bacteria variation with time and voltage for flushing water (x-axis indicates the treatment time while the $y$-axis indicates the amount of bacteria).

TABLE III: BACTERIA VARIATION WITH TIME AND ELECTRIC VOLTAGE FOR FLUSHING WATER

\begin{tabular}{cccc}
\hline Time (mins) & \multicolumn{3}{c}{ Bacteria (/plate) } \\
\hline & $10 \mathrm{~V}$ & $20 \mathrm{~V}$ & $30 \mathrm{~V}$ \\
\hline 0 & 29 & 28 & 28 \\
15 & 26 & 25 & 22 \\
30 & 26 & 17 & 5 \\
45 & 25 & 13 & 0 \\
60 & 23 & 5 & 0 \\
\hline
\end{tabular}

From the data, it is noted that the amount of bacteria decreases by increasing the electric voltage. The electric voltage of $25 \mathrm{~V}$ or $30 \mathrm{~V}$ is the best voltage.

2) The effect of electric voltage on free chlorine content

The effect of electric voltage on the generation of free chlorine by the electro-photo-disinfection system was determined by varying the voltage from 10 to $30 \mathrm{~V}$ at different contact time. The results of free chlorine generation at different voltage and different contact time were illustrated in Fig. 7.

Under lower voltage $(10 \mathrm{~V})$, the current was small in the system, therefore, the rate of free chlorine formation was also very slow. When the voltage was increased to $20 \mathrm{~V}$, the rate of chlorine generation was significantly increased. The concentration of free chlorine in the water reached about 1.1 $\mathrm{mg} / \mathrm{l}$ after 60 -minute operation.

As the electric voltage was further increased to $30 \mathrm{~V}$, the formation of free chlorine was substantially increased due to the higher current applied. The reaction time required to generate $1.1 \mathrm{mg} / \mathrm{l}$ free chlorine was shortened to $15 \mathrm{mins}$ for $30 \mathrm{~V}$. As the electrolysis went on, the concentration of free chlorine accumulated. This indicated that the system is capable of generating a free chlorine production rate that reaches a dynamic equilibrium with the rate of chlorine consumption in the flushing water disinfection process. 
The concentrations of free chlorine formed under various electrode voltages are presented in Table IV. When chloride concentration was controlled above a certain value, the formation of free chlorine was positive and was proportional to the electric voltage applied across the electrodes. The higher the voltage applied in electrode, the higher rate of free chlorine formation in the water. The electric voltage should be applied to the system for effective disinfection is shown in Table IV, in order to acquire sufficient free chlorine (1 to 3 $\mathrm{mg} / \mathrm{l})$ in the fountain water for effective disinfection. The optimum operational condition of this system is $30 \mathrm{~V}$.

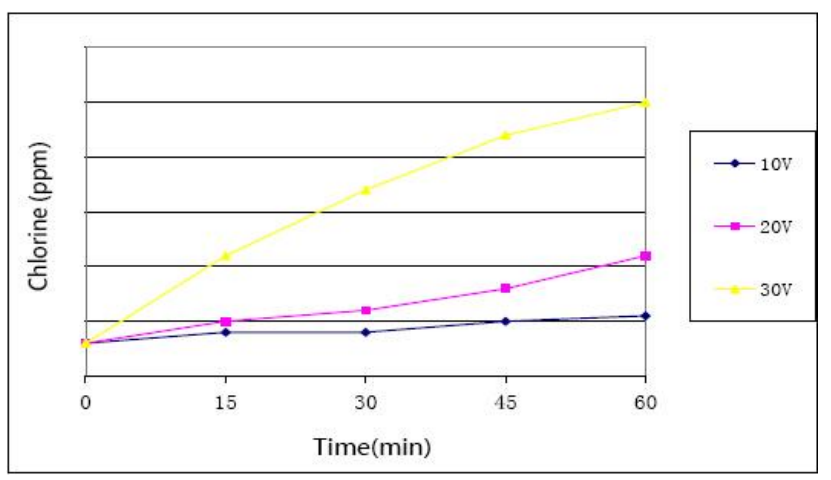

Fig. 7. Chlorine concentration variation with time and voltage for flushing water.

TABLE IV: CHLORINE CONCENTRATION VARIATION WITH TIME AND ELECTRIC VOLTAGE FOR FLUSHING WATER

\begin{tabular}{cccc}
\hline \multirow{2}{*}{ Time (mins) } & \multicolumn{3}{c}{ Chlorine content $(\mathrm{ppm})$} \\
\cline { 2 - 4 } & $10 \mathrm{~V}$ & $20 \mathrm{~V}$ & $30 \mathrm{~V}$ \\
\hline 0 & 0.3 & 0.3 & 0.3 \\
15 & 0.4 & 0.5 & 1.1 \\
30 & 0.4 & 0.6 & 1.7 \\
45 & 0.5 & 0.8 & 2.2 \\
60 & 0.55 & 1.1 & 2.5 \\
\hline
\end{tabular}

From the data, it is noted that the amount of free chlorine increases by increasing the electric voltage. The electric voltage of $25 \mathrm{~V}$ or $30 \mathrm{~V}$ is the best voltage.

Based on the results, it can conclude that with the increasing of electric voltage, the free chlorine content would be increased. As a result, the disinfection efficiency increases accordingly for the flushing water.

\section{CONCLUSION}

The PCO system used in this study was found to have good disinfection function on fountain and flushing water. Under the electric voltage of $25 \mathrm{~V}$ to $30 \mathrm{~V}$, the bacteria content was decreased while the free chlorine content was increased. This increased free chlorine content would contribute to the increased disinfection efficiency of the fountain and flushing water in the domestic water used in real estate.

\section{ACKNOWLEDGMENT}

Authors would like to thank the financial support from the Teaching Company Scheme under The Hong Kong Polytechnic University.

\section{REFERENCES}

[1] J. Zhao and X. Yang, "Photocatalytic oxidation for indoor air purification: a literature review," Building and Environment, vol. 38, no. 5, pp. 645-654, 2003

[2] M. Zhang, Q. Wang, C. C. Chen, L. Zang, W. Ma, and J. Zhao "Oxygen atom transfer in the photocatalytic oxidation of alcohols by $\mathrm{TiO}_{2}$ : oxygen isotope studies," Angewandte Chemie, vol. 48, no. 33, pp. 6081-6084, 2009.

[3] Q. L. Yua and H. J. H. Brouwers, "Indoor air purification using heterogeneous photocatalytic oxidation. Part I: Experimental study," Applied Catalysis B: Environmental, vol. 92, no. 3-4, pp. 454-461, 2009.

[4] J. Ananpattarachai, P. Kajitvichyanukul, and S. Seraphin, "Visible light absorption ability and photocatalytic oxidation activity of various interstitial N-doped $\mathrm{TiO}_{2}$ prepared from different nitrogen dopants,' Journal of Hazardous Materials, vol. 168, no. 1, pp. 253-261, 2009.

[5] Y. Chen, A. Lum, Y. Li, L. Zhang, H. Y. Yip, H. Zhao, T. An, and P. K Wong, "Naturally occurring sphalerite as a novel cost-effective photocatalyst for bacterial disinfection under visible light," Environmental Science and Technology, vol. 45, no. 13, pp 5689-5695, 2011.

[6] J. H. Castillo-Ledezma, J. L. Sánchez Salas, A. López-Malo, and E. R. Bandal, "Effect of $\mathrm{pH}$, solar irradiation, and semiconductor concentration on the photocatalytic disinfection of Escherichia coli in water using nitrogen-doped $\mathrm{TiO}_{2}$," European Food Research and Technology, vol. 233, no. 5, pp. 825-834, 2011.

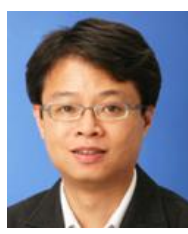

C. W. Kan is an associate professor in the Institute of Textiles and Clothing, The Hong Kong Polytechnic University. Dr. Kan earned his BSc and PhD degrees in textile chemistry from the Hong Kong Polytechnic University. His research major is in the field of textile coloration and finishing, surface modification of textile materials and environmental management. Dr. Kan has worked extensively in his research fields and has published more than 80 peer-reviewed journal and conference articles.

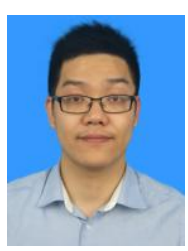

Y. N. Pan is a PhD candidate in the Institute of Textiles and Clothing, The Hong Kong Polytechnic University. Mr. Pan earned his BSc degree from Huazhong University of Science and Technology. His research major is in the field of environmental engineering and waste water treatment.

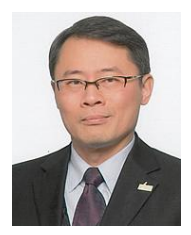

H. Chua is a professor in the Faculty of Science and Technology, Technological and Higher Education Institute of Hong Kong. Prof. Chua earned his BEng and $\mathrm{PhD}$ degrees in chemical engineering and environmental engineering respectively from National University of Singapore. His research major is in the field of water resource and wastewater treatment, indoor air quality control, odour pollution control, solid waste recycle and reuse and food safety. Prof. Chua has worked extensively in his research fields and has published more than 200 peer-reviewed journal and conference articles. 